\title{
STUDY OF THE PATTERN OF HOMICIDAL DEATHS IN VARANASI REGION OF INDIA
}

Rajeev Kumar1

\section{HOW TO CITE THIS ARTICLE:}

Rajeev Kumar. "Study of the pattern of homicidal deaths in Varanasi region of India". Journal of Evolution of Medical and Dental Sciences 2013; Vol. 2, Issue 43, October 28; Page: 8393-8418.

ABSTRACT: BACKGROUND: The Indian penal code defines homicide as the killing of human being by another human being. OBJECTIVE: Study pattern of homicidal deaths in Varanasi region of India METHOD: The present study comprised of homicidal deaths in medicolegal autopsies held in the mortuary of the department of Forensic Medicine, Institute of Medical Sciences, Banaras Hindu University, Varanasi, U.P., India, during the period from 1st July 1999 to $30^{\text {th }}$ Nov. 2000. RESULTS: It was observed that $23.01 \%$ of total autopsies were homicidal death and $4.73 \%$ were homicide by firearm and explosives. Maximum victims of homicides was due to firearm injury constituting 18.10 percent of total homicides. This was followed by sharp weapon (17.69\%), blund weapon (16.87\%) and asphyxiation (16.46\%). Burning was the causes in 16.04 per cent and drowning in 4.54 per cent. Mixed weapon /method was responsible for 4.11 per cent of homicide, poisoning (3.73\%) and explosive (2.46\%). It is to be ovserved that firearm and explosive together comprised 20.56 per cent of total homicide. Age and sex distribution of victims of homicise by fire arm and explosive was also studied and observed that most of the victims (94\%) were male and only few victims (6\%) were female. Over majority (62\%) were young adult in the age group of 21-40 years.18 \% victims were of middle age (41-50 years). Adolesecents comprised $10 \%$. Only $2 \%$ of victims were old aged, 61 Years and above. There were two female victims in the age group 31-40 years and one victim in the age group of $0-10,11-20,41-50$ and 61 and above. Most of the victims (93\%) of homicide by firearm and explosive were hindu followe by Muslims (5\%) and Sikhs 1\% Religion of one victim could not be ascertained. Over majority $51.61 \%$ of hindu victims belonged to upper caste followed by lower casts $40.86 \%$ and schedule casts $7.52 \%$.Of the total of five muslim victims, four were sunni and one belonged to shiya sect. There were no victims belonging to Christian or Buddhist. Religion/caste of one victim could not be known. CONCLUSION: There has been a phenomenal rise in the use of firearms and explosives for committing various crimes leading to death of victims. This spurt in its use may be attributed to the deteriorating socio-economic, and law and order situation as also easy availability of both licit and ilicit as well as improvised or country made firearms and explosives all over India.

KEY WORDS: Homicidal deaths, Medicolegal autopsies.

INTRODUCTION: The dilemma of violent crime including that of murder has baffled equally all the developed and the underdeveloped societies of the world. The phenomenon of murder (criminal homicide) is of heinous nature: its incidence is quite widespread but its understanding is limited and rare. With the growth of civilization, there has been a corresponding increase in the rates of crime including murder. Since the dawn of the history, man has engaged himself in offering explanations of the increasing rates of crime and murder in the society. The controversy as to the underlying factors is still raging without any universally acceptable explanation in sight. As a part of the explanation, the primitive societies believed the act to be the result of evil spirits and demons and the guilt and 


\section{ORIGINAL ARTICLE}

the innocence were established by a variety of procedure that called forth the supernatural allies of the accused.

The act of murder has the quality of absolute finality, relatively unusual among other crime, as the consequences for the victim cannot be underdone. In a civilized society a very high premium is placed on the sanctity of human life, so the killing of another human being is the ultimate renunciation of behavior norms. Consequently, murder holds unusual fascination as a subject for fiction and research.

Johnson (1966) said "crime like murder are crimes of emotionally" Wolfgang (1969) asserts that "murder is most often impulsive, violent and explosive act". According of Cormier (1962) "murder occurs at a point of intense emotion and feeling that to continue (the relationship) is inconceivable and to give up impossible".

Murder is possible only in terms of a given socio-cultural mould. Hence, socio-cultural background may be regarded as the primary basis in determining the characteristics of criminal homicide.

Killing of human being is one of the most serious of major crimes. Since very long time laws were framed by different judicial authority in a bid to prevent its further occurrence. Inspite of all there has been a phenomenal rise in the incidence of homicide all over the world and also in India, perhaps due to a highly intensified struggle for survival in the face of industrialization and urbanization.

In the commission of very offence, excepting a few, there are two parties, the perpetrator and the victim. Therefore, every offence requires an objects-per sonal and impersonal. The object may be an active one as case of pickpocketting, fight, cheating, etc. or passive one as in case of extortion, robbery, dacoity, murder etc. In either case the victim may be superior, inferior or equal to the perpetrator in the personal, physical, mental and social characteristics. Hence the relationship between the offender and the victim becomes intricate.

Criminologists explain criminal homicide by posing question like: why does this individual commit murder? What is the impact of various institutions such as family, religion, education on him, so that he is led to commit murder? In what way do his personal characteristics contribute to such a behaviour?

If sociologists were to see murder as the product of interaction between the murderers and victims and in varying circumstances the result of their study would focus on general proposition that could be formulated about the structure and development of interactive process that produce murder. Naturally, explanation of murder differs depending upon the approach one adopts for its examination.

It concentrates, not on circumstances and influences, but on the criminal act itself. If it breaks the social contract of the law, the act should be punished proportionally with unwavering certainty, severity and impartiality.

In the classical approach, the question whether the accused intended to commit the act, and whether the accused was in his right frame of mind and could thus be held responsible for his actions, as a rational individual, was of crucial importance. The cause of murder related to the question of rational motivation. Therefore, the source of criminal homicide is located within the 'rational individual'. The central focus in classical criminal policy is the criminal act itself (Morris, 1974). 
One of the most debated among the theories is the "born criminal" theory of Lombroso (1911) who thought that the typical murderer was a born criminal and attributed this to atavism or "throw back" to lower animal and methodological ground in his studies.

Ardrey (1966) believed that the instinctual nature of human aggression was the cause of criminal homicide. He thought weapons came first and that human brain developed to serve a violent life style. Murder, therefore, is a natural behaviour. Aichihorn (1963) in his writing accept psychoanalytical viewpoint of murder. He claims that criminal homicide is due to unconscious desire of an individual.

The psychoanalytical theory of criminal behaviour is erroneous mainly because, it assume instincts. It is obvious that human behaviour is not a product of biological forces alone. Psychoanalytic view of the behaviour of criminal homicide is defective because it stresses the impact of experience of infancy and early childhood (Devasia \& Devasia, 1992). Frustration- aggression theory suggest the murder might occur when a person is frustrated and his effort to obtain some goal is obstructed (Dollard, 1961).

One School of thought believes that regional social values exercise influence on the behaviour of the people to take to decent ways. Sutherland (1978) demonstrates that different subcultures and social group exist with varying social values. Such regional and other kind of social pluralism help account for the varied patterns of crime that are observed in different parts of American communities.

Numerous sociologists consider murder as a way of conforming to the expectations of subculture that differ from the dominant middle class culture (cohen. 1955). Violent sub-culture are highly touchy. Those who belong to sub-Culture degrade certain situation, the other group would find unimportant, as a serious challenge to their integrity.

Secondly, the norms of such sub-cultures requires violent response to such challenges.

"Quick resort of physical combat as a measure of daring courage; or defense of status appear to be cultural expression "(Wolfgang and Ferracuti 1967).

Merton (1976) stated that the rates of criminal behaviour is highest where people have little access to socially legitimate means for achieving culturally induced goals. Where the conflict arises between cultural goals and institutionalized means for their achievement is great, a condition of anomic develops. It is the breakdown of regulative norms; and people then turn to adopt whatever means to achieve the goal. Parsons (1964) also explained that "the popular antithesis of full institutionalization is anomic - the complete breakdown of normatic order".

Cohen (1965). Kornhanser (1978). Turner and Turner (1978) and gibbons (1987) explained the ambiguous and incomplete nature of the theory of anomie to provide a clear and accurate account of the factory that are involved in deviant activities of any kind.

REVIEW OF LITERATURE: Crime is a problem that has taxed all the individual and societies since times immemorial. The rise of civilization has only added to the increase and diversification in crime. The pattern of crime is changing and enlarging. Crime, today is infecting parts of body social to which, hitherto, it has been able to spread political murders, hitherto unknown to criminal calendar have appeared and crime violence are rapidly increasing in volume and gravity. Rather, it can be said that crime is a by product of civilization (Sharma, 1985).

Homicide is one of the most serious crime in modern society and it usually receives the most severe penalties, including death sentence. Ordinarily, homicide is classified as a crime against the 
person, along with aggravated assault, rape and so on. Since it has the individual rather than property as it focus, it is overwhelmingly committed by a single individual upon another single individual.

Homicide consists of two words i.e. Homa-means man and cide-means cut. The Indian penal code defines homicide as the killing of human being by another human being (devasia and devasia, 1992)

Homicide is just killing by the one who plan the death of another with malice and forethought, one who looks a purpose to kill but means to inflict serious injury only and the one who act in want of disregrad of human life (Eckert, 1977).

In due course the maxim of English Criminal Law was followed, Which says "A man's act doesn't make him guilty unless his mind also is guilty "Mens rea" MacMillon, 1944).

In murder related with crime, the victim may be the criminal who is killed during an attempted robbery or during siege. The homicide may result a dispute between prisoner or between guards and prisoners.Massive beating with heavy weight or pushing victims from a height often characterize such cases (Eckert, 1977).

Murder have long been associated with activities of criminal elements engaged in organized crimes. Such murders may be planned or disguised or bluntly brutal in order to dramatize the fate of the victim or victims among his family or associates, and to set an example. A staged killing may be designed to cover up the professional aspect of the killing, and an elaborate plan may be devised for the disposal of the body (Tedesch, 1977).

Group murder exist, but very infrequently, when a group focuses on one individual, seeking to kill him. Various labels are used: lynching, popular justice, mob action. In many preliterate and historic society members of clans sought "blood revenge" killing in this instance was part of family or clan feuds and very often went unpunished by tribe, village, or community when one group seeks to combat and exterminate another group, the phenomenon is called massacre, and war, the liquidation of deviationist by the rating clique is looked upon as consolidation or defense and goes unpunished as murder, likewise the liquidation of the leaders of the losing side in a rebellion or revolution is also political expending and is not viewed as murder (Rackless, 1971).

Miethe et al. (1994) studied "crime and its social context". They argued the major theories of criminality are rejected for their forces or the behaviour of individual offenders and relatives neglect of aspect of the social environment that facilitate crime,for of which are discussed : Socio-economic status, residential mobility, ethnic heterogenity and single parent families. These factors are integrated into a theory of crime that stresses the relationship between offenders victims and social context. Further, it is seen that such.

Indicators as population mobility, family disruption, public transportation and family income are significant predictors of crime rate in a given community.

It would seem easy to derive prediction about homicide using Durkehiem's (1897) conc epts, accordingly low level of social regulation in society would be expected to lead to increased rates of all kind of deviant behaviour including homicide.High level of social integration might lead to increased rates of homicides between friends and relatives in reaction to the frustration constraints of close interpersonalities. In contrast low levels of social integration might lead to increased rates of homicide between strangers. 
Lombroso's positivism and the Darwinion Philosophy of human nature flourished during the last half of the $19^{\text {th }}$ century. Lombroso,s theory of a born methodological basic. Later on. Lombroso modified his view and develop the positive approach which emphasized that crime, is a natural phenomenon caused by variety of factors (Multiple causation), Some of which are biological and other environmental.

Durkheim, however, theorizes that the most popular path to nowhere is biologism, according to which men violate the criminal code out of a hereditary, constitutional compulsion to do so. This view dies hard despite a hundred years of sterile speculation and misbegotten research (Singh, 1990).

Lester (1998) examined 53 nations in 1980 to see whether predictions based on Dukheim theory of suicide and homicide, but a measure of social regulation was positively associated with suicide rate and negatively associated with homicide rate.

Friendlander (1947) reported that unfavorable environment play a part in criminal homicide but only as a precipitating cause that encourage murderous behaviour repressed in normal person.

Frustration-aggression theory suggest that murder might occur when a person is frustrated and his effort to obtain some goal is obstructed. Other scholars have also tried to show the influence of frustration aggression theory on the incidence of criminal homicide (Palmer, 1968: sill, 1968:Saran,1974:Devasia and Devasia, 1985: Berkowith, 1986).

Aichihorn(1963) in his writing accepts psychoanalytical view point of murder. He claims that criminal homicide is due to unconscious desire of an individual.

Murderous behaviour result when the restraining forces are too weak to curb in there aggressive and destructive tendencies (Hallack, 1967).

Individual who have no employment, who are alcoholic and drug addicts, who are mentally ill and who lack close ties with friend and family, may be close to the group of murderers (Chakrawarty, 1982).

\section{Crime Rate*}

\begin{tabular}{|c|c|c|}
\hline \multirow{2}{*}{ Country } & \multicolumn{2}{|c|}{ Year } \\
\hline & 1990 & 1991 \\
\hline Argentina & 177.05 & 114.05 \\
\hline Austria & 60002.70 & 6074.30 \\
\hline Belgium & 3337.80 & 3639.30 \\
\hline Canada & 11913.00 & 12735.00 \\
\hline Egypt & 3314.40 & 3666.61 \\
\hline India & 592.26 & 594.29 \\
\hline Netherlands & 7613.00 & 9507.00 \\
\hline England \& wales & N.A. & 10403.00 \\
\hline Japan & 1396.50 & 1450.00 \\
\hline Spain & 2635.08 & 2482.78 \\
\hline Singapore & 1672.80 & 1629.40 \\
\hline U.S.A & N.A. & 5897.80 \\
\hline
\end{tabular}

Comparative crime rates-India and some selected countries

Source: Crime in India, 1933 


\begin{tabular}{|l|c|c|}
\multicolumn{3}{c}{ Murder* } \\
\hline \multirow{2}{*}{ Country } & \multicolumn{2}{c|}{ Year } \\
\cline { 2 - 3 } & 1990 & 1991 \\
\hline Argentina & 0.14 & 0.06 \\
\hline Austria & 2.30 & 2.50 \\
\hline Belgium & 2.20 & 3.20 \\
\hline Canada & 2.00 & 3.00 \\
\hline Egypt & 1.60 & 1.60 \\
\hline India & 4.23 & 4.61 \\
\hline Netherlands & 15.00 & 21.00 \\
\hline England \& Wales & N.A. & 3.00 \\
\hline Japan & 1.00 & 1.00 \\
\hline Spain & 2.43 & 2.33 \\
\hline Singapore & 1.60 & 1.80 \\
\hline U.S.A & N.A. & 9.80 \\
\hline \multicolumn{3}{|c|}{$\begin{array}{c}\text { Comparative crime rates-India } \\
\text { and some selected countries }\end{array}$} \\
\hline \multicolumn{3}{|c|}{}
\end{tabular}

Crime Rate*
\begin{tabular}{|l|c|c|}
\hline \multirow{2}{*}{ Country } & \multicolumn{2}{|c|}{ Year } \\
\cline { 2 - 3 } & 1992 & 1993 \\
\hline Bangladesh & 63.93 & 62.97 \\
\hline Canada & N.A. & 10954.70 \\
\hline China & N.A. & 124.38 \\
\hline Hing kong & 1446.37 & 1394.90 \\
\hline India & 604.79 & 614.79 \\
\hline Indonesia & 113.39 & 59.24 \\
\hline Japan & 1466.31 & 1509.65 \\
\hline Nepal & 13.34 & 16.87 \\
\hline Singapore & 1560.22 & 1494.19 \\
\hline Sri Lanka & 280.11 & N.A. \\
\hline $\begin{array}{c}\text { Comparative crime rates -India } \\
\text { and some selected countries }\end{array}$ \\
\hline
\end{tabular}

Murder

\begin{tabular}{|l|c|c|}
\hline \multirow{2}{*}{ Country } & \multicolumn{2}{c|}{ Year } \\
\cline { 2 - 3 } & 1992 & 1993 \\
\hline Bangladesh & 2.21 & 1.99 \\
\hline Canada & N.A. & 5.63 \\
\hline China & N.A. & 1.95 \\
\hline Hing kong & 2.15 & 1.55 \\
\hline India & 4.62 & 4.32 \\
\hline
\end{tabular}




\begin{tabular}{|l|l|l|}
\hline Indonesia & 0.80 & 0.84 \\
\hline Japan & 0.99 & 0.99 \\
\hline Nepal & 2.55 & 2.32 \\
\hline Singapore & 1.53 & 2.02 \\
\hline Sri Lanka & 8.13 & N.A. \\
\hline
\end{tabular}

Comparative crime rates -India and some selected countries

\begin{tabular}{|c|c|c|c|c|c|c|c|c|c|c|c|}
\hline $\begin{array}{c}\text { Crime } \\
\text { heads }\end{array}$ & 1984 & 1985 & 1986 & 1987 & 1988 & 1989 & 1990 & 1991 & 1992 & 1993 & 1994 \\
\hline $\begin{array}{c}\text { Total } \\
\text { murders }\end{array}$ & $\begin{array}{c}25786 \\
(3.5)\end{array}$ & $\begin{array}{c}25970 \\
(3.5)\end{array}$ & $\begin{array}{c}27269 \\
(3.6)\end{array}$ & $\begin{array}{c}28513 \\
(3.6)\end{array}$ & $\begin{array}{c}28771 \\
(3.6)\end{array}$ & $\begin{array}{c}31222 \\
(3.8)\end{array}$ & $\begin{array}{c}35045 \\
(4.2)\end{array}$ & $\begin{array}{c}39174 \\
(4.6)\end{array}$ & $\begin{array}{c}40105 \\
(4.6)\end{array}$ & $\begin{array}{c}38240 \\
(4.3)\end{array}$ & $\begin{array}{c}38577 \\
(4.3)\end{array}$ \\
\hline $\begin{array}{c}\text { Murders in } \\
\text { UP(state) }\end{array}$ & 6324 & 6599 & 6836 & 6985 & 6502 & 7594 & 8151 & 9994 & 10559 & 10589 & 10776 \\
\hline $\begin{array}{c}\text { Murder in } \\
\text { Varanasi } \\
\text { (District) }\end{array}$ & 106 & 109 & 115 & 103 & 109 & 116 & 116 & 149 & 205 & 226 & 166 \\
\hline $\begin{array}{c}\text { Murder in } \\
\text { Varanasi } \\
\text { city }\end{array}$ & 22 & 25 & 26 & 23 & 26 & 26 & 58 & 72 & 62 & 70 & \\
\hline \multicolumn{7}{|c|}{$\begin{array}{c}\text { Table: Incidence and volume of murder and under different } \\
\text { crime heads and percentage during 1994 in Varanasi. }\end{array}$} \\
\hline
\end{tabular}

percentage during 1994 in Varanasi.

Source:

Crime In India

National crime Record Bureau

Ministry of Home Affairs

East Block- VII, R.K. puram

New Delhi-110 066

DEFINITION: Firearm: Any instrument or device with which it is possible to propel a projectile by the expansive force of the gases generated by combustion of explosion substance (Wilhelm, 1973).

Bomb: It is a container filled with an explosive mixture and missiles, which is fired either by detonator or a fuse. When an explosion occurs, the explosive material produces a large volume of gas, and releases a large amount of energy.

Homicide: Homicide, in general, is killing of one human being by another. Homicide embraces killing by the one who plans the death of another with malice afore thought, the one who lacks a purpose to kill but means to inflict serious injury only and the one who acts with disregard to human life (Exkert, 1977).

Fatality by firearm and explosives presents problem of great concern to law-enforcement agencies as well as the Forensic pathologist. With the advent of industrialization there is rapid increase in use of fire arms and this has led to a phenomenal rise in the incidence of fire arm fatalities (Fattch, 1973). 


\section{Epidemiological Aspects:}

Age: In a study of 425 homicide victims carried out in Houston, U.S.A., Pokorny (1965) found the maximum number of cased (47.5\%) was between 20 - 34 years of age, while $58 \%$ of the offenders were in the 20 - 39 years age group.

In a nine years study (1965 - 73) of homicides in Chicago by Richard Block (1975) found that the highest number of victimization for blacks occurred in the late teens and early twenties. The peak among the whites was in the late middle age and old age.

Gupta et al. (1979) analysed 89 case of firearm deaths in Varanasi area and found that $33.67 \%$ cases were drawn from the age group of 31 to 40 years followed by $(28.08 \%)$ the cased who came under 21 - 30 years.

Ranjan et al. (1981) studied incidence of murders in Bangalore and Delhi during the years 1970 - 79 and found that most of the victims were young, below 30 years in age and were married.

Out of the 372 case of homicides reported by Das Gupta et al (1983) from Varanasi area during 1978 - 79 reported that most of the cases (48.41\%) were young adults (25 - 44 years) followed by those (27.41\%) who were middle aged (45-64) and $14.24 \%$ were adolescents (15-24 years).

Sex: Out of the 425 homicide victims studied in Houston by Pokorny (1965) 341(80.2\%) were males and only 84 (19.8\%) were females. IN the same study out of the 430 homicide offenders $73.7 \%$ were males, $23 \%$ were females and the sex of the remaining $3.3 \%$ cases were unknown.

Out of the 553 homicide victims studied in Chicago by Frank Zimring (1968) as much as 80\% victims were males and only $20 \%$ were female. In the same study out of the 485 an overwhelming offenders (82.7\%) were males and only 84 (17.3\%) were females.

Out of the 22 firearm deaths reported by Bhaskaran et al (1969) all were males.

Fetech et al. (1974) in their study observed that out of a total of 2087 firearm victims, as many as 1727 (82.2\%) were males and a mere 360 (17.2\%) were females.

Analysis of 1006 victims of homicide by the same author further revealed that an overwhelming number of victims $839(83.4 \%)$ were males and the rest (16.6\%) were female.

Richard Block (1975) in his study noted that most (523 or 86.16\%) of the total 607 homicidal firearm victims were males and only 84 (13.84\%) were females.

Gupta et al. (1979) analyzed 82 cases of homicidal firearm deaths and showed that as many as $79((96.34 \%)$ were males.

Religion and Caste: Religion does not merely represent the faith in the unknown, it also denoted the cultural mode of life, individuals and groups belongs to a particular religious group, have much in common, which differentiate them from other.

Wolfgang (1958) in his study of homicide during 1984 - 1952 at Philadelphia found that $73 \%$ victim were Negro, white $75 \%$ of offenders were Negro.

Pokorny (1965) in his study of homicidal death the Haustan reported that maximum (32.3\%) of the victims were Negroes followed by Latin Americans (12.15\%), while whites were 5.5\% only.

In another similar study at Chicago, Voss et al. (1968) found that out of 394 homicidal victim, $56.6 \%$ were non white males followed by non-white females $(21.32 \%)$.

Subramanyam et al. (1978) observed that $96.4 \%$ victims were Hindus and only $3.6 \%$ were Muslims. 


\section{ORIGINAL ARTICLE}

Krishna (1981) showed that the proportion of the Hindu - victims was substantially higher, in Bangalore (79\%) and Delhi (87\%). It may be generally remarked that in Bangalore the victims belonging to Hindu religion were somewhat under - represented as compared to Delhi.

Das Gupta and Tripathi (1983) in their analysis of homicidal deaths in Varanasi found that 87.63\% victims were Hindu followed by $4.83 \%$ Muslims. The Religion of 6.72 remained unknown.

Santomba (1985) reported that as to religious affiliation of the Victims, overwhelming majority (85.89\%) where Hindus and only $2.65 \%$ where muslims and in $11.53 \%$ cases religion could not be ascertained.

Rai (1987) from their study made evident that over majority of victims were Hindus (72.94\%) followed by Muslims (18.82\%). In rest 8.24\% cases victims were unknown.

Roy (1994) showed that $89.75 \%$ or victims were Hindus and rest $10.24 \%$ were Muslim. There were Muslim. There was no Christian or Sikh among the victims.

Fornes et al. (1996) in their series found a majority of victims were Caucasians (60\%), whereas 30\% were Arabics, 5\% were Asian and 5\% were Blacks.

The caste system is a distinctive feature of India society. Determined by birth, the system has elaborate rule practices governing inter marriage, inter dining and so on. So pervasive has been the influence of the system that it has survived several exogenous cultural influences and has even permeated other religious group like Christians, Muslims and Sikhs - untouchability has been abolished under the Civil Right Act and the principal of universal franchise has been in operation for the last 30 years or more, further, the so called lower caste groups have been provided selective opportunities for upliftment. There are reservation in schools and colleges in economic assistance and job opportunities and now in Assemblies and Parliament. Many sociologists, however, doubt if these measures have narrowed caste cleavages.

Krishna (1981) observed that in Bangalore, a fairly large number of the victims belonged to scheduled caste (29\%) and scheduled tribe (21\%) followed by Brahmins (17\%), while in Delhi majority of victims belongs to Kshatriya (40\%) and Brahmins (19\%).

Community Character: Sill (1968) pointed out that according to U.s. Federal Bureau of investigation, the homicide rate in standard U.s. metropolitan statistical areas was 4.9 in 1960. All other cities had a lower rate of 3.8 and rural areas had a higher rate of 6.4.

In many studies (Gupta and Sethi, 1974; Singh and Verma, 1976; Sharma, 1976; Gupta and Srivastava, 1977), a very high occurrence of murder has been observed in rural area.

Gupta et al. (1979) found the percentage distribution of community character of the firearm victims and recorded $43.82 \%$ rural, $21.95 \%$ urban and $17.17 \%$ suburban of Varanasi area.

Singh (1980) in his study "a study of per sonality of murders and psychosocial factors related to murder" observed that majority of murderers belonged to rural areas.

Das Gupta et al. (1983) in their study showed preponderance of rural $(65.86 \%)$ over the urban $(17.17 \%)$ victims in firearm fatalities. However, a small fraction $(10.2 \%)$ belonged to suburban area of Varanasi.

Nabachandra (1984) found that community character of homicidal firearm fatalities were overwhelming rural (78.05\%) and only $21.59 \%$ were drawn from the urban population.

Nagpaul (1985) explained that in American Society homicide rate used to be higher in rural community or region that urban communities till fifties. 


\section{ORIGINAL ARTICLE}

Santomba (1985) reported that maximum number (41.02\%) of the victims were from rural area followed by urban area (24.35\%), suburban $(23.07 \%)$. The community character of $(11.53 \%)$ could not be ascertained.

Rai (1987) found that community of the overwhelming majority were rural $(64.71 \%)$ followed by urban (16.47\%) and suburban $13(15.29 \%)$ in the victims of homicide by blunt weapons.

Roy (1994) recorded the habitat of victims of homicidal as $48.29 \%$ rural followed by $24.39 \%$ urban and $12.19 \%$ suburban and $15.12 \%$ cases were unidentified.

Education: It is axiomatic to state that education equips the individual to face the realities of life. Both formal or informal modes of education enable the individuals to adjust himself in the community in a meaningful way. This way, to a great extent, keep the educated away from the antisocial path. Likewise, the educated are also likely to be more aware of the circumstances and situations which would imperil their survival. The expectation, therefore, would be that the educated would be less likely to fall victim of crime including homicide.

Krishna (1981) reported that the nature and extent of formal education of homicide victims differs in the two cities Delhi and Bangalore. In terms of literacy primary (7\%), and junior high school (63\%) in Bangalore has an edge over Delhi. In contrast in terms of higher education high school $(22 \%)$ graduate $(12 \%)$ etc. the position is almost reversed. In any case a majority of the victims were literate and the date thus do not show that most of the victims were illiterate.

Nabachandra (1984) reported about the literacy of the victims in their study as $31.71 \%$ illiterate, $26.83 \%$ educated up to primary level and 3.66\% were graduates.

Santomba (1985) revealed that as much as $44.87 \%$ victims were illiterate, $24.25 \%$ were educated at various levels and in $28.22 \%$ cases educational status could not be ascertained.

Rai (1987) observed that $34.12 \%$ victims were illiterate, $24.71 \%$ educated upto primary level and the percentage of victims tends to decline as literacy increased and none of them was graduate.

Roy (1994) revealed about educational status of the fatally assaulted people as $32.68 \%$ illiterate, $25.36 \%$ could go upto primary standards, $19.02 \%$ educated upto secondary and another $11.70 \%$ upto higher secondary only.

However, there were 8 (3.90\%) graduate, 3 (1.46\%) post graduate and 2 90.97\%) professionals.

Marital Status: Mckinley (1964) has found marital status to be a significant determinant in child bashing (B.P.R.D. 1981).

Similarly, Samasundar (1970) stated that murder is often a domestic affair and that more married women are killed in their bed room.

As against this, Hidelang et al. (1978) observed that there is less likelihood of married and widow women getting victimized as compared with unmarried and separated women.

Krishna (1981) found in Bangalore, 49\% victims were married while 51\% were unmarried, while in Delhi 62\% victims were married and 37\% victims were unmarried and 1\% was widow / widower. Most of the married victims (31\%) have been killed because of the dispute arising over money matter as against this a sizeable proportion of the unmarried victims (23\%), were killed 


\section{ORIGINAL ARTICLE}

because of personal enmity (or inter personal as also sex dispute). The involvement of the menvictims in disputes over money matters is however supported by the fact that most of them (57\%) were killed by men offenders.

Kopsowa et al. (1994) have studied the effect of marriage on male and female homicide in the United States during the period of 1979 - 1985. Their analysis indicate that marriage offers significant immunity against homicide victimization especially for males. After controlling for socio demographic characteristics married mal es were found to have a 38\% lower risk.marriage increased that risk by $46 \%$. The beneficial effect of marriage was greater for those with larger family sizes and/or inner city residence.

Occupation: Asuni (1969) in his study of homicide victims in West Nigeria concluded that to traditional group 40.38\% victims were farmers or small land holders, followed by fisherman, laborer, petty traders (7.69\% each) and traditional healer whereas remaining $34.61 \%$ were non traditional including motor drivers sawyears, cornmell operators, brick layers and domestic stewards.

Subhramanyam et al. (1978) reported a high percentage of a agriculturists $50.0 \%$ and businessman $18.30 \%$ in their series of fatal firearm victims labourer (5.92\%) and students (4.30\%) and remaining $44.6 \%$ were dacoits, robbers, thieves and other antisocial elements.

Tosayanand (1984) revealed that over majority of victims $55.66 \%$ were employed in office and factories, followed by employed (17.85\%) and house wife (11.54\%), students (6.68\%), government officials and self employed (6.62\%) and 1.5\% were children.

Nabachandra (1984) observed in their stubby that largest occupational group was farmer (30.14\%) followed by business and dacoits (14.63\% each) among the firearm homicidal victims of Varanasi.

Whereas, Santomba (1985) is his series of sharp weapon fatalities recorded $32.05 \%$ agriculturists, $25.51 \%$ laboures, $25.91 \%$ businessman, $7.6 \%$ housewives, $5.12 \%$ servicemen and $3.82 \%$ students as occupation.

Rai (1987) observed that largest occupational group among the victims of homicide by blunt weapon were agriculturists (35.29\%) followed by servicemen (16.47\%), labourer (14.12\%) household industries (8.24\%), businessman (7.06\%) and students (4.71\%).

Chimbos (1993) while analyzing the occupation of offenders and victims of homicide found that $73 \%$ of the offenders and $46 \%$ of the victims whose occupation were known to news reporters came from these occupational categories. Persons who were not employed, disable or minors comprised $15.4 \%$ of the offenders and $28.6 \%$ of the victims.

Similarities in the socio-economic background of homicide offenders and their victims have been reported by many researchers in other countries including the United States (Wolfgang, 1958; Manford et al., 1976) and Canada (Jayawardene, 1975; Chimbos, 1978).

At the same time above study show that the percentage of the victim $(17 \%)$ in the professional, managerial and business properties categories is higher than that of offenders (6.3\%). A possible explanation for this variation is the occurrence of political assassinations and robbery related homicide of small businessmen. The relatively high percentage (28.6\%) of victims among persons who were not employed reflects homicides against the Greek elderly during burglary or robbery. 
Roy (1994) found over all number of homicidal victims involved in agriculture occupation were highest $(36.58 \%)$ followed by the business community $(17.07 \%)$, labourer $(12.68 \%)$, service people (7.31\%), student (6.82\%), house wife (6.46\%) and unemployed (2.92\%).

\section{MATERIAL AND METHODS:}

Material: The present study comprised of 100 (one hundred) cases of homicidal firearms and explosives injuries drawn from the medicolegal autopsies held in the mortuary of the department of Forensic Medicine, Institute of Medical Sciences, Banaras Hindu University, Varanasi, U.P., India, during the period from 1st July 1999 to $30^{\mathrm{M}}$ Nov. 2000, accompanied by sufficient number of relevant persons who were thoroughly interviewed at the time of autopsy on the body of deceased victim of homicide by firearm and explosives.

For the study relevant questionnaires schedule were prepared to collect various data, Socioeconomic factors, data about incidence of fatal firearm and explosive death, data about medicolegal crime investigation and evidential data etc. These cases were studied for the history of the cases, their epidemiological characteristics eg. age, sex, community character etc. nature, distribution and types of injuries including their medicolegal aspects.

Methods: The various data relating to the cases were collected from sources as under :

a. examination of inquest reports and connected papers.

b. interviewing the police person nel accompanying the cases.

c. interviewing the relatives, friends and neighbors of the deceased, and

d. the autopsy examination paper.

The various data pertaining to each case was collected by the methods as indicated above so as to provide information on the following points:

1. History as regard s date, time and place

2. Epidemiological features

\section{In Regard to Victims}

1. Age,

2. Sex,

3. Religion/caste,

4. Community character, Rural/urban/suburban.

5. Educational status,

6. Physical status

7. Marital status

8. Mental status

9. Personal habits

10. Drug habits

11. Personal hobby

(i) Indoor

(ii) Outdoor

1. Dependents 
2. Family type

3. Occupational status

4. Family occupation

5. Income

(i) Personal \&

(ii) Family

1. Apparel

2. Activity at the time of incidence

3. Position at the time of incidence

4. What did victim do after receiving the injury

5. Whether victim required medical care or not and was operated or not after sustaining the injury,

6. Whether any other person was injured

7. Who first saw the victim and who informed to the police about the incidence

8. Condition of victim on arrival of police

9. Whether the police recovered the victim alive/dead

OBSERVATION AND RESULTS: In the present study, a total of 100 cases of homicide by firearm and explosives drawn from the medicolegal autopies of Varanasi area including Chandauli carried out in the memory od Department of Forensic Medicine of Institute of Medical Sciences, Banaras Hindu university,Varanasi, During the period from 1.7.99 to 30.11.2000 (17 months).

\begin{tabular}{|c|c|c|c|c|c|c|}
\hline $\begin{array}{c}\text { Total no of } \\
\text { Autopsies }\end{array}$ & \multicolumn{2}{|c|}{$\begin{array}{c}\text { Total No of } \\
\text { homicidal death }\end{array}$} & \multicolumn{2}{c|}{$\begin{array}{c}\text { Death from firearm and } \\
\text { explosive injuries }\end{array}$} & $\begin{array}{c}\text { Death from homicidal firearm } \\
\text { and explosives injuries }\end{array}$ \\
\hline & Number & $\%$ & Number & $\%$ & Number & $\%$ \\
\hline 2112 & 486 & 23.01 & 100 & 4.73 & 100 & 4.73 \\
\hline
\end{tabular}

Table given above shows total homicidal death and also incidence of firearms and explosive injuries in medicolegal autopsies and their nature of death.It is observed that $23.01 \%$ of total autopsies were homicidal death and $4.73 \%$ were homicide by firearm and explosives.

\begin{tabular}{|l|c|c|}
\hline \multicolumn{1}{|c|}{ Methods } & Numbers & \% of total homicide \\
\hline Firearm & 88 & 18.10 \\
\hline Sharp Weapon & 86 & 17.69 \\
\hline Blunt Weapon & 82 & 16.87 \\
\hline Asphyxiation & 80 & 16.46 \\
\hline Burning & 78 & 16.04 \\
\hline Drowning & 22 & 4.54 \\
\hline Mixed Weapon/method & 20 & 4.11 \\
\hline Poisoning & 18 & 3.73 \\
\hline
\end{tabular}




\begin{tabular}{|l|c|c|}
\hline Explosive & 12 & 2.46 \\
\hline & Table 2: Methods employed for causing homicide \\
during the period from 1.7.99 to 30.11.2000.
\end{tabular}

The above shows that maximum victims of homicides was due to firearm injury constituting 18.10 percent of total homicides. This was followed by sharp weapon (17.69\%), blunt weapon $(16.87 \%)$ and asphyxiation (16.46\%). Burning was the causes of 16.04 per cent and drowning in 4.54 per cent.Mixed weapon /method was responsible for 4.11 per cent of homicide, poisoning $(3.73 \%)$ and explosive $(2.46 \%)$. It is to be observed that firearm and explosive together comprised 20.56 per cent of total homicide.

\begin{tabular}{|c|c|c|c|}
\hline Age group (years) & Male & Female & Total/Percentage \\
\hline $0-10$ & - & 1 & 1 \\
\hline $11-20$ & 9 & 1 & 10 \\
\hline $21-30$ & 30 & - & 30 \\
\hline $31-40$ & 30 & 2 & 32 \\
\hline $41-50$ & 17 & 1 & 18 \\
\hline $51-60$ & 7 & - & 7 \\
\hline 61 and above & 1 & 1 & 2 \\
\hline \multicolumn{4}{|c|}{ Table 3: Age and sex distribution of } \\
\hline & 94 & 6 & 100 \\
\hline
\end{tabular}

Above table shows age and sex distribution of victims of homicide by fire arm and explosives. It is observed that most of the victims (94\%) were male and only few victims (6\%) were female.

Over majority (62\%) were young adult in the age group of $21-40$ years.18 \% victims were of middle age (41-50 years). Adolescents comprised $10 \%$. Only $2 \%$ of victims were old aged, 61 Years and above.There were two female victims in the age groups 31-40 years and one victim in the age group of 0-10, 11-20,41-50 and 61 and above.

\begin{tabular}{|c|c|c|c|c|c|}
\hline Hindu & $\begin{array}{c}\text { Lower } \\
\text { Casts }\end{array}$ & $\begin{array}{c}\text { Scheduled } \\
\text { Casts }\end{array}$ & Muslim & Other religion & Unknown \\
\hline Upper casts & & & & & \\
\hline Brahmin & Ahir-13 & Harizan-2 & Siya-1 & Sikhs-1 & 1 \\
\hline Thakur-18 & Sunar-1 & Kalwar-1 & Sunni-4 & Christian-Nil & \\
\hline Vishya-15 & Kurmi-1 & Kewat-1 & & Buphist-Nil & \\
\hline Kaystha-5 & Khatri-1 & Kahar-1 & & & \\
\hline & Tamoli-1 & Nut-1 & & & \\
\hline & Teli-7 & & & & \\
\hline & Mali-2 & Kunbi-1 & & & \\
\hline
\end{tabular}




\section{ORIGINAL ARTICLE}

\begin{tabular}{|c|c|c|c|c|c|}
\hline & Carpenter-3 & & & & \\
\hline & Yadav-9 & & & & \\
\hline 48 & 38 & 7 & 5 & 1 & 1 \\
\hline & 93 & & & 7 & \\
\hline & & 100 & & & \\
\hline
\end{tabular}

Table 4: Regional and casts distribution of victims of homicide by firearms and explosives.

Table given above shows that the most of the victims (93\%) of homicide by firearm and explosive were Hindu followed by Muslims(5\%) and Sikhs 1\% Religion of one victim could not be ascertained. Over majority $51.61 \%$ of Hindu victims belonged to upper caste followed by lower casts $40.86 \%$ and schedule casts $7.52 \%$ of the total of five Muslim victims, four were sunni and one belonged to siya sect.There were no victims belonging to either Christianity or Buddhism. Religion/caste of one victim \ could not be known.

\begin{tabular}{|c|c|}
\hline Community Character & Percentage \\
\hline Rural & 44 \\
\hline Urban & 32 \\
\hline Suburban & 24 \\
\hline & 100 \\
\hline
\end{tabular}

Above table on community character of victims of homicide by firearm and explosives, reveals that the max no 44 of victims came from rural areas followed by urban area 32 and suburban area 24.

\begin{tabular}{|c|c|}
\hline Marital Status & Percentage \\
\hline Married & 65 \\
\hline Unmarried & 21 \\
\hline Widow & 1 \\
\hline Widower & 5 \\
\hline Divorcee & 3 \\
\hline Separated & 4 \\
\hline Unknown & 1 \\
\hline
\end{tabular}

Above given table for marital status victims of homicide by firearm and explosives shows that majority $65 \%$ were married followed by unmarried $21 \%$, widower 5\%, Divorcee 3\% .One victim was a widow and marital status of one victim could not be known. 
ORIGINAL ARTICLE

\begin{tabular}{|c|c|}
\hline Occupation & Percentage \\
\hline Agriculture & 35 \\
\hline Business & 15 \\
\hline Service & 12 \\
\hline Unemployed & 10 \\
\hline Student & 9 \\
\hline Unstable job & 7 \\
\hline Labourer & 6 \\
\hline House wife & 4 \\
\hline Unmarried Girl & 1 \\
\hline Unknown & 1 \\
\hline & 100 \\
\hline
\end{tabular}

Table 7: Occupational status of victims of

homicide by firearm and explosives.

Table above reveals that the occupation of max $35 \%$ victims was agriculture followed by businessman $15 \%$ service 12\%, Unemployed 10\%, Student 9\%. Seven \% victim had unstable job, 6 $\%$ labourer. Four $\%$ victims were house wife and one $\%$ unmarried girl and occupation of one victim could not be known.

\begin{tabular}{|c|c|}
\hline Family occupation & Percentage \\
\hline Agriculture & 45 \\
\hline Business & 20 \\
\hline Service & 18 \\
\hline Unstable job & 9 \\
\hline Labourer & 7 \\
\hline Unknown & 1 \\
\hline
\end{tabular}

Above given table shows that agriculture was family occupation of max $45 \%$ victims followed by businessman $20 \%$, service $18 \%$, unstable job $9 \%$, Labourer $7 \%$, and family occupation of one victim could now be known.

\begin{tabular}{|l|l|}
\hline Educational Status & Percentage \\
\hline Illiterate & 28 \\
\hline Below primary & 26 \\
\hline Primary & 13 \\
\hline Secondary & 9 \\
\hline Intermediate & 8 \\
\hline Under graduate & 8 \\
\hline Post graduate & 7 \\
\hline
\end{tabular}




\section{ORIGINAL ARTICLE}

\begin{tabular}{|l|l|}
\hline Unknown & 1 \\
\hline & 100 \\
\hline $\begin{array}{l}\text { Table 9: Educational Status of victims } \\
\text { of homicide by firearms and explosives. }\end{array}$ \\
\hline
\end{tabular}

Above table on educational status of victims of homicide by firearms shows that max $28 \%$ victims were illiterate followed by those below primary $26 \%$ and primary $13 \% .9 \%$ victims were of secondary level $8 \%$ were of intermediate level, Undergraduate 8\%, Post Graduate 7\%.Educational status of one \% victim Could not be known.

\begin{tabular}{|l|l|}
\hline \multicolumn{1}{|c|}{ Physical status } & Percentage \\
\hline Average & 55 \\
\hline Well built & 25 \\
\hline Weak & 10 \\
\hline Very Weak & 6 \\
\hline Emaciated & 4 \\
\hline
\end{tabular}

Table 10: Physical Status of victims of firearm and explosives.

Table given above clearly shows that over majority $55 \%$ of victims were of average built followed by well built 25\%, Weak 10\%. $6 \%$ Victims were weak and 4\% emaciated.

DISCISSION: For the present study, a total of 100 cases of homicide by firearms and explosives were taken from the medicolegal autopsies of Varanasi area that were carried out in the mortuary of department of forensic medicine, Institute of medical sciences, Banaras Hindu university, Varanasi during the period from $1^{\text {st }}$ July 1999 to $30^{\text {th }}$ Nov 2000. These were studied and analyzed with special reference to their epidemiological and medicolegal aspects.

Incidence of Firearm and Explosive Fatalities: The present study (table 1) on firearm and explosive fatalities revealed that out of total of 2112 medicolegal autopsies carried out in the mortuary of department of forensic medicine of institute of medical science, 1999 to November 2000, as many as 100 (4.73\%) cases were due to fatalities from firearm and explosive injuries and all of them were homicidal in nature.

Further our study have shown (Table 2) that out of 486 (23.01\%) homicidal deaths that occurred during above period, maximum (18.10\%) cases were due to firearm and only $2.46 \%$ were by explosives and thus together constituting $20.56 \%$ of total homicide.This was followed by homicide by sharp weapons (17.69\%), by blunt weapons (16.87\%) and asphyxiation (16.46\%), whereas burn cases were the causes in $16.04 \%$, drowning in $4.54 \%$, multiple weapon in $4.11 \%$ and poisoning in 3.86\% homicidal deaths.

Wolfgang (1958) in his study of 588 homicide cases found that the highest no (38\%) of fatalities were caused by stabbing followed by the who are, rather, protected and shielded, again by males from criminal exposures I $n$ the family as well as society. 


\section{ORIGINAL ARTICLE}

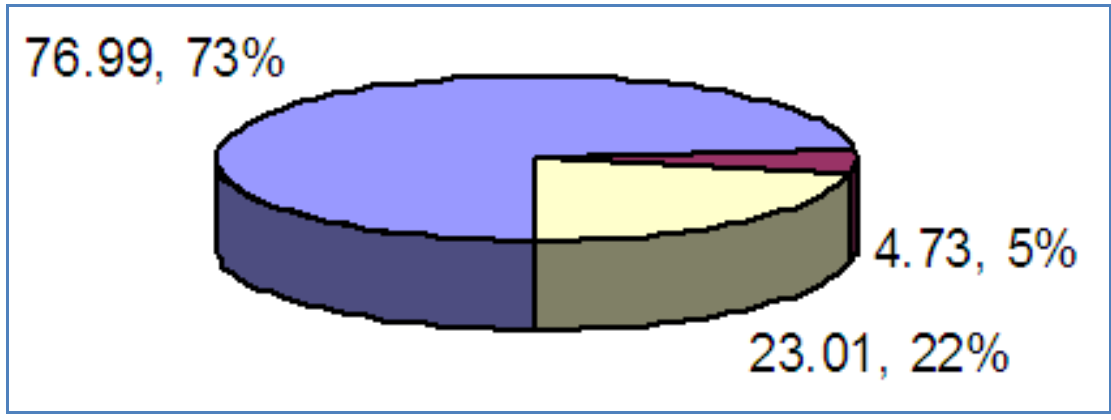

Incidence of homicide by firearm and explosives in medicology autopsies (in per cent)

Total no of autopsies except homicides

Total no of homicidal death except homicide by firearm and explosives

Death from homicidal firearm and explosive injuries

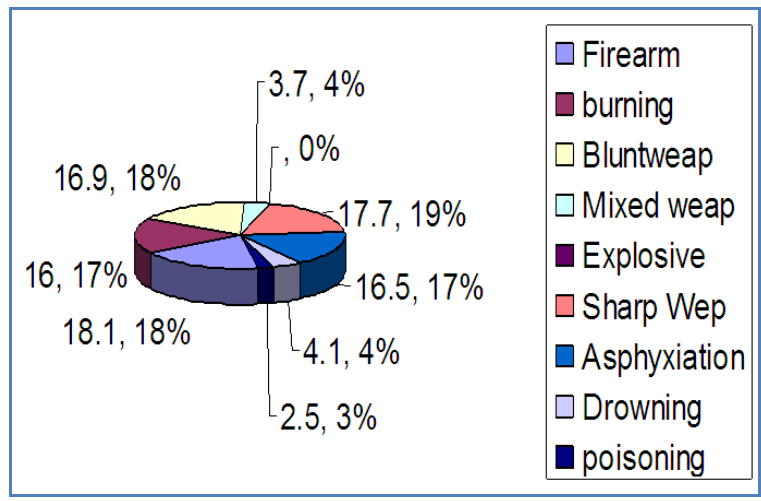

Methods employed for causing homicide

The preponderance of male over female in homicidal fatalities have been consistently reported by most of the workers from all over the world including in this country. Wolfgang (1958) found that 76 per cent victims were males. Similar preponderance of males as homicidal victims were reported by Pokomy (1965) - 73.7\%, Fattech et al. (1974) - 83.4\%, Subramanyam et al. (1978) - 95\% Das Gupta et al. (1983) - 88.97\% Tosayanand (1984) - 89.96\%, Nabachandra (1984) - 89.02\%, Santomba (1985) - 88.47, Chandra et al. (1986) - 86.42\%, Daradkesh (1988) - 66\%, Copeland (1989) - 77.1\%, Moncat et al. (1991) - 64.3\%, Murphy (1991) - 70\%, Chimbos (1993) $62.3 \%$ and Roy (1994) - 78.04\% male victims.

Age Distribution of Victims:Our study (Table 3) on age distribution of the homicidal victims revealed that maximum number of victims (32\%) were drawn from age group 31-40 years and another $30 \%$ victims were aged between $21-30$ years. Thus over majority (62\%) of victims came from adult (21-40 years) age group. As much as 25 per cent victims came from middle age group 41 -60 years.

This preponderance of adult age group (21 - 40 yrs) being more commonly victims of homicide may be attributed to the fact the persons in this age group bears the thrust of 
responsibilities of various kind s including family, social, economic and status etc. and in carrying out the responsibility they have to interact quite frequently with other persons and in the process they are bound to clash with other persons upon their interests entangled or inter twinned with those of other. Also the young adult persons being more enthusiastic and energetic, are generally ready to fight than to flight or to compromise. Persons in this age group are also not so mature to calculate about the net loss or gain or to restrain themselves from such fights or clashes that are liable to make them victims of homicide. These persons being more

Adventurous and optimistic often lack patience and reasoning and fail to fight out their enemies (assailants) and become more commonly victims of homicide in the process.

Prkorny (1965) observed that maximum number of homicide victims (47.5\%) were between 20 - 34 years of age, while Voss et al. (1968), reported as much as $44.3 \%$ victims between $24-40$ years.

Fatteh (1974) found $45.10 \%$ victims between 21 to 40 years and Gupta et al. (1979) recorded as high as $61.75 \%$ victims in the age group 21 - 40 years. Krishna (1981) in Bangalore reported $49 \%$ victims between 20 - 39 years while in Delhi they were as much as $61 \%$.

Das Gupta et al. (1983) found 48.11\% Tosayanand (1984) 57.9\%, Nabachandra et al. (1984) 60.98\%, Santomba et al. (1985) 49.49\%, Chandra et al. (1986) 59.25\%, Daradkeh (1988) 55.3\% and Roy (1994) recorded (50.92) victims belonging to the age group of $20-40$ yrs.

Further, in the present study as much as 10 per cent victims were found in the age group 10 - 20 yr., (of and around adolescent). In a similar study Tosayanand (1984) also found 20.3\% homicidal victims in the age group of 10 - 19 years.

Still further our study revealed that there were 25 per cent victims belonging to the middle years age group of 41.60 years. Our findings are similar to those of others, Krishna found in Bangalore $16 \%$ victims in the age group of 40 - 59 and in Delhi these were 15\%. Tosayanand (1984) also reported $17.61 \%$ victims in the age group of $40-59$ yrs.

It appears that middle aged persons in the age group of 46 - 60 yr. are more mature and compromising and do not frequently involve themselves, at least physically, in fights rather they remain behind the scene or avoid their involvement.

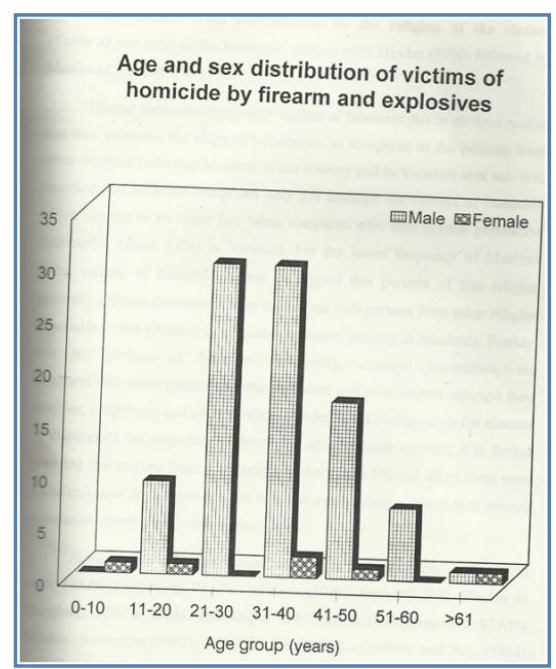

Religion of the Victims:It is evident from our analysis on the religion of the victims (Table 4) that most of the homicidal victims were Hindus (93\%) followed by Muslims (5\%) and Sikh (1\%). 


\section{ORIGINAL ARTICLE}

Hindus were most frequently victims of homicide due to obvious reason that they comprise the majority population, as compared to the persons from other religions including Muslims in our country and in Varanasi area too. It is recorded that Muslims comprised only 5\% amongst the victims of homicide which appears to be rather low when compared with their normal population distribution (about (14\%) in Varanasi. For the lower frequency of Muslims being victims of homicide it may be argued that persons of this religion generally restricts themselves from interaction with persons from other religion especially in the situation of disputes and crime leading to homicide. Further, that the persons of Muslims community, amongst themselves, are comparatively more integrated, interdependent and even related amongst their families, neighbours and other relations, Under above backgrounds the chances of disputes of the magnitude of homicide, are obviously reduced. It is further revealed that victims from other religions were only $1 \%$ and all of them were Sikhs and none from other religion which is nearly comparable to their normal population distribution in this region.

Similar observation were also reported by Subramanyam et al. (1978) with Hindu comprising 96.4\% Krishna (1981) reported 79\% Hindus in Bangalore, 87\% in Delhi, Das Gupta and Tripathi (1983) reported 87.63\% Hindus. Santomba (1985) - 85-89\%, Rai (1987) - 72.94\% and Roy (1994) recorded $89.75 \%$. Hind us as victims of homicide in their series of studies on homicide.

Caste Distribution of the Victims: The comparison of caste distribution (Table 4) of homicidal victims in Varanasi area revealed that amongst various casted, Thakur (Kshatriyan) were highest (18\%) followed by Vaishya (15\%), Ahir (13\%), Brahmin (10\%) and Yadav (9\%). If the victims are grouped into the conventional three traditional major social caste categories, it is observed that nearly majority (48\%) of victims were drawn from upper castes (Brahmin, Thakur, Vaishya, Kayasthat) followed by victims (38\%) from lower caste (Ahir, Sunar, Kurmi, Khatri, Tamoli, Teli, Mali, Carpenter and Yadav) and only 7\% victims were drawn from scheduled castes (Harizan, Kalwar, Kewat, Kahar, Nut and Kunbi).

The predominance of upper caste being more frequent victims of homicide is most probably due to presence of many of the factors that leads to homicidal situations in the people of upper casted which may result into their homicidal victimization. Too.

The common factors of homicidal situation are property, (fixed, movable) holdings, prestige and position consciousness, personal revenge, parental enemity, protection liabilities, promotional liabilities for socioeconomic and status, power care, political affiliation and aspirations purchasing tendency, punishing desired, procuring ambition, perverted ideation, [personality deviations and disorders and paranoid traits.

Krishna (1981) found in Delhi that maximum number of victims belonged to Kshatriya (40\%) followed by Brahmin (19\%) and Vaishya (13\%) whereas in Bangalore, a fairly large number of victims belonged to scheduled caste (29\%) and scheduled tribe $(21 \%)$ followed by Brahmin (17\%), Ksthtriya (12\%) and Vaishya (4\%). It revealed that in Bangalore upper caste were 33\%, lower caste $17 \%$ while scheduled caste were $50 \%$ and in Delhi upper caste victims were over majority (73\%) followed by scheduled caste $16 \%$ and lower caste (9\%).

Community Character of Victims:Community character of homicidal victims in the present study (Table 5) depicted that maximum victims (44\%) were drawn from rural area followed by urban (32\%) and suburban (24\%) population. 
Apart from other reasons, the preponderance from rural over urban and suburban victims of homicide may be due to the fact that the normal population or rural habitat is about twice than the urban and suburban in Varanasi area (Rural 69\%, urban and suburban 31\% as per 1991 census). Other reason could be that there are more frequent disputes over landed and other properties in the rural areas, more family oriented disputes in rural families comprising large number of members and perhaps more rigid / fixed and lasting family enmities of generations in rural population as compared to urban people. It may be said that there are more opportunities of cross personal, familial and social interaction and clashes upon objects of common interests in rural than urban areas and also more mutual interdependency in rural, while more independency in urban people.

This preponderance of victims from rural over urban and suburban habitat in consistent with the findings of other in this regard. Gupta et al. (1979) found the percentage distribution of community characters of firearm victims as $73.82 \%$ rural, 21.95 urban and 17.17 suburban in Varanasi area. Das Gupta et al. (1983) reported preponderance of rural (65.68\%) over urban $(17.17 \%)$ and suburban (10.2\%) victims of homicide in Varanasi area. Nabachandra (1984) found that community character of homicide firearm fatalities were overwhelmingly rural $(78.05 \%)$ santomba (1985) reported that maximum number $(41.05 \%)$ of victims were from rural area followed by urban area (24.35\%) and suburban habitat (23.07\%).

Rai (1987) reported that community character of overwhelming majority were rural (64.71\%) followed by urban (16.47\%) and sub urban (15.29\%) in the victim of homicide (1994) recorded that habitat of maximum (48.2\%) victims were rural followed by urban (24.39\%) and suburban (12.19\%) population.

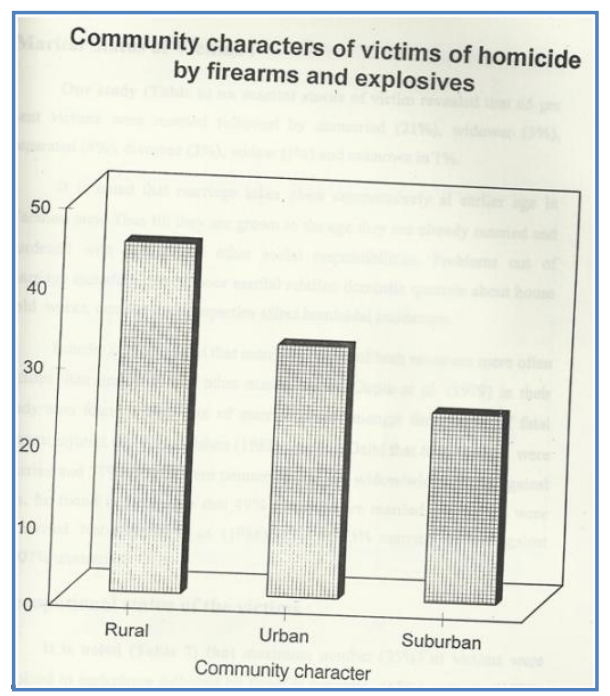

Marital Status of Victims: Our study (Table 6) on marital status of victim revealed that 65 percent victims were married followed by unmarried (21\%), widower (5\%), separated (4\%) divorcee (3\%) widow (1\%) and unknown in $1 \%$.

It is noted that marriage takes place comparatively at earlier age in Varanasi area. Thus till they are grown to the age they are already married and burdened with family and other social responsibilities. Problems out of marriage including dowry, poor marital relation domestic quarrels about house hold works, conflict over properties affect homicidal incidences. 
Schofer (1976) opined that married persons of both sexes are more often victims than person in any other marital status. Gupta et al. (1979) in their study also found a high rate of married cases amongst the victims of fatal firearm injuries (80.91), Krishna (1981) found in Delhi that $62 \%$ victims were married and $37 \%$ victims were unmarried and $1 \%$ widow/widower. As against this, he found in Bangalore that 49\% victims were married while 51\% were unmarried. Nabachandra et al. (1984) noted 70.73\% married victims against 17.07 unmarried.

Occupational status of the victims: It is noted (Table 7) that maximum number (35\%) of victims were involved in agriculture followed by those in business (15\%), Service (12\%), Unemployed $(10 \%)$, student (9\%) unstable job (7\%), Labour (6\%), house wife (4\%) unmarried girl (1\%) and unknown (1\%).

It may be said that persons in agriculture occupation were more vulnerable to be homicidal victim in Varanasi. This may be explained by the fact that there are large population engaged in agriculture, secondly civil disputes on landed properties commonly among agriculture land lords are long lasting so much so that even in courts, litigation continue over generations and sporadic criminal clashes occurs between the parties leading to homicidal victimization more frequently.
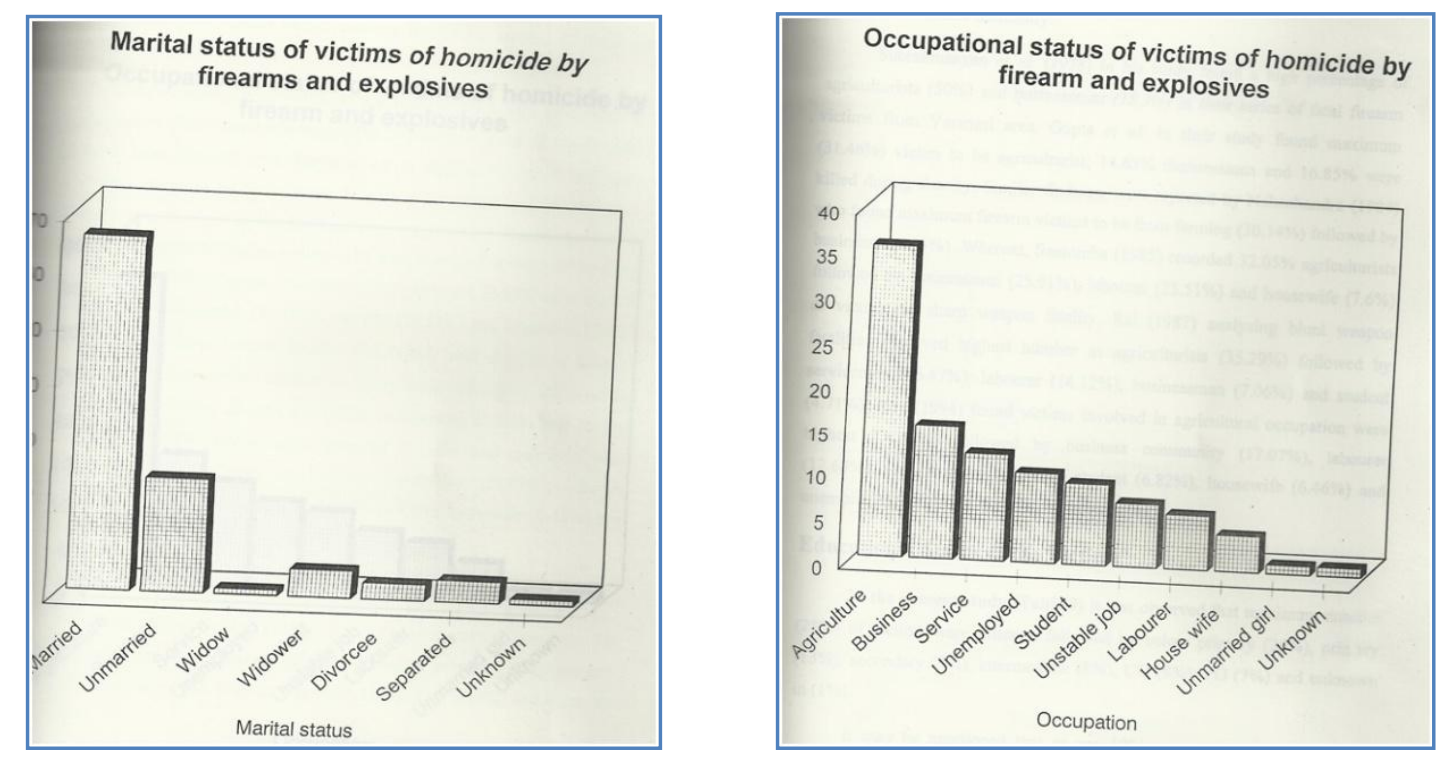

Subrahmanyan et al. (1978) in his study found a high percentage of agriculturists (50\%) and businessmen (18.3\%) in their series of fatal fiream victims from Varanasi area Gupta et al. in their study found maximum (31.46\%) victim to be agriculturist, 14.63 businessmen and 16.85\% were killed during dacoity. Similar findings, were reported by Nabachandra (1984) who found maximum fiream victims to be from farming (31.14\%) followed by business (14.63\%). Whereas, Santomba (1985) recorded 32.05\% agriculturists followed by businessmen (25.91\%), labourer (25.51\%) and housewife (7.6\%) as victims of sharp weapon fatality. Rai (1987) analyzing blunt weapon fatalities observed highest number as agriculturists (35.29\%) followed by servicemen $(16.47 \%)$ labourer (14.12\%) businessman (7.06\%) and student (4.71\%). Roy (1994) found victims involved in agricultural occupation were highest (36.58\%) followed by business community $(17.07 \%)$, labourer 
(12.68\%), Service people (7.31\%), student (6.82\%), housewife (6.46\%) and unemployed $(2.42 \%)$ in descending frequencies.

Educational Status of the Victims: In the present study (Table 9) it was observed that maximum number $(28 \%)$ of victims were illiterate followed by below primary (26\%) primary (13\%) secondary (9\%) intermediate (8\%) UG (8\%), PG (7\%) and unknown in (1\%).

It may be mentioned that as per 1991 census report on literacy of Varanasi di strict, only $27.3 \%$ were literate amongst which $40 \%$ literacy was recorded for male and $13.3 \%$ for female. The preponderance of illiteracy amongst population is bound to influence incidences of crimes including homicidal victimization. Seeing the above proportion of illiteracy in the normal population from where the subject of our study were drawn, it may be said that the proportion of illiterate victims were not as larger as their proportion in the general population suggests.

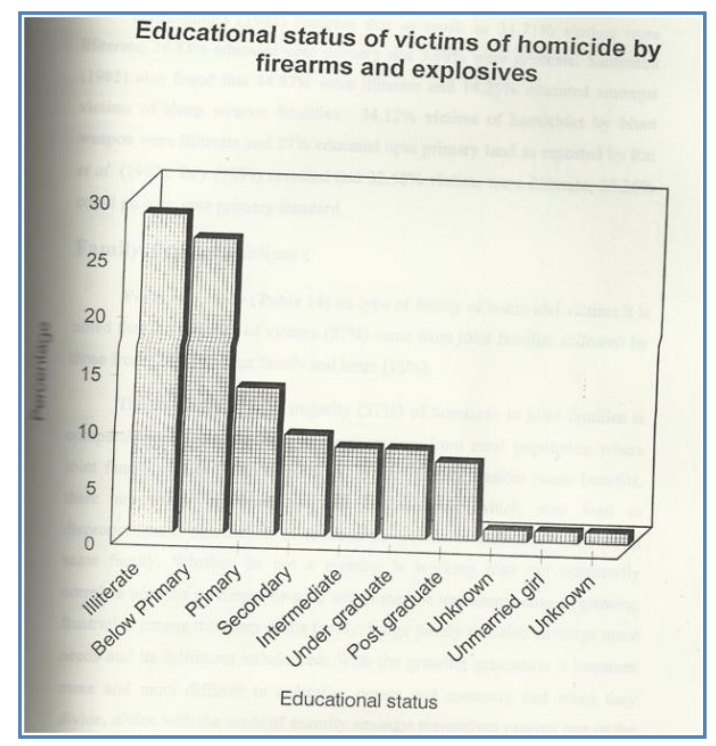

Nabachandra (1984) reported that as much as $31.71 \%$ victims were illiterate, 26.83 educated upto primary and $3.66 \%$ were graduate. Santomba (1985) also found that $44.87 \%$ were illiterate and $14.25 \%$ educated amongst victims of sharp weapon fatalities. 34.12 victims of homicides by blunt weapon were illiterate and $27 \%$ educated upto primary land as reported by Rai et al. (1987). Roy (1994) revealed that $32.68 \%$ victims were illiterate, $25.63 \%$ could go only upto primary standard.

\section{SUMMARY AND CONCLUSION:}

SUMMARY: One hundred cases of homicide by firearm and explosive drawn from the medicolegal autopsies brought to the mortuary of Department of Forensic Medicine, Institute of Medical Sciences, Banaras Hindu University, Varanasi, U.P. India during the period from 1st July, 1999 to $30^{\text {th }}$ November 2000, were studied for a detailed epidemiological and medicolegal analysis. The important highlighting findings of the study are summarised as under:

1. Out of total 2112 autopsies, conducted during the above period 100 (4.73\%) victims had died of homicidal firearm and explosive injuries. 
2. Firearms and explosive were involved as weapons in 100 (20.56\%) out of total 486 homicide cases autopsied during the said period.

3. Out of total of 100 victims studied 94 per cent were males and 6 per cent females and the largest number of victims came from the age group of 31 to 40 years (32\%) followed by those between 21 to 30 years (30\%).

4. Most of the homicidal victims were Hindus (93\%) and among them Thakurs were 18 per cent.

5. Maximum number of victim (44\%) came from rural areas followed by urban (32\%) and suburban (24\%) population.

6. Nearly two third of homicidal firearm and explosive victims (65\%) were married.

7. Highest number of homicidal firearm and explosive victims were agriculturists (35\%) followed by businessman (15\%).

8. Family occupation of maximum victims (45\%) were also agriculture followed by business in (20\%).

9. Maximum number (28\%) of victims of homicidal firearm and explosive injuries were 'illiterate.

10. Majority of the victims (55\%) of homicidal firearm and explosive were of average built.

CONCLUSION: There has been a phenomenal rise in the use of firearms and explosives for committing various crimes leading to death of victims. This spurt in its use may be attributed to the deteriorating socio-economic, and law and order situation as also easy availability of both licit and ilicit as well as improvised or country made firearms and bombs all over India.

The ever expanding areas of individual and mass violence including political terrorism, communal violence, dacoities, smuggling across the international and state borders kidnapping for ransom and hijacking of aircrafts have all contributed their share to the phenomenal size in the use of firearm and explosives resulting in many a homicide fatalities. Hardly a day passes in the life of a Forensic Pathologist working in one of the autopsy centres mainly in the northern part of India including Varanasi area, where he is not required or called upon to perform medicolegal autopsy examination on a victims of alleged death from firearm discharge.

But in view of the complexities created by the introduction of newer and newer improvised and conventional firearms and explosives in most of the areas, the establishment of various facts in a cases of firearm death, such as the type of weapon used, the range of firing, the direction of fire, the number of shots fired, wound of entry and exit and the damage to vital parts and the like, have become fraught with serious and many fold difficulties/complexities for the Forensic Pathologists as also of the Ballistics.

The present study based on Varanasi area has provided a number of revealing informations as summarised above regar ding the homicidal firearm and explosive deaths, that are certainly going to be of much help to the Forensic pathologists and members of law enforcing agencies in understanding the various epidemiological, motivational, socio-cultural and pathological characteristics of the homicidal firearm and explosive fatalities occurring in this part of the country. Further and more in depth studies using many more parameters over larger series of firearm and explosive death, are. strongly indicated. 


\section{BIBLIOGRAPHY:}

1. Adelson L. (1953): Medical Evidence in Fatal Gunshot Injuries. Am. J. Clin. Path. 23:758-767.

2. Adelson L. (1961): A Microscopic Study of Dermal Gunshot Wounds. Am. J. Clin. Path. 35 : 393-402.

3. Adelson L. (1974): Pathology of Homicide. Edn. Charles Thomas Publisher. 188-318.

4. Andrasko J. and Machly A.C. (1977): Detection of Gunshot Residues on Hands by Scanning Election Microscopy. Jr. Fors. Scs. 22(3): 279-287.

5. Asgakar M.D. et al. (1972): Determination of Gunshot Firing Distances. Arkiv. Jur. Krim. 149:1975.

6. Asuni (1969): Homicide in Western Nigeria. Brit. J. Psychiatry. 115:1105-13.

7. Bakshi H.N. (1960): Synopsis of Medical Jurisprudence : Medical Book \& Co., Calcutta, 6th Edn., pp. 98-109.

8. Barner, H.E. and Teeters, N.K. (1961): New Horizon in Criminology. $3^{\text {rd }}$ Edition, p. 148.

9. Bartal, Curt R. and Bartal, Ami M. (1986): Criminal Behaviour - A Psycho Social Approach. New Jersey, Prentice Hall. No. 198, pp. 165-166.

10. Bureau of Police Research and Development (1983): Ministry of Home Affairs. Govt. of India, III.

11. Cameron, J.M. (1974): Changing Pattern of Violence. Med. Sci. Law. 13(4):264.

12. Cardarell, Albert P. (1968): An analysis of police killed by criminal action, 1961-63. Jr. Crim. Law and Criminology. 59(3):447-453.

13. Chandra, J., Dogra, T.D. and Dikshit, P.C. (1986): Comprehensive Study of Homicide in South Delhi.

14. Crime in India (1978): Bureau of Police Research and Development. Ministry of Home Affairs Government of India.

15. Crime of India (1979): Bureau of Police Research and Development, Ministry of Home Affairs, Govt. of India.

16. Crime of India (1986): National Crime Records Bureau. Ministry of Home Affairs. Government of India.

17. Crime of India (1993): National Crime Records Bureau. Ministry of Home Affairs. Government of India.

18. Crime of India (1994): National Crime Records Bureau. Ministry of Home Affairs. Government of India.

19. Das Gupta S.M. and Tripathi C.B. (1983): A Study of the Homicide Cases Occurring in Varanasi Area. Indian Medical Gazette. CXVII(9):285-288.

20. Das Gupta S.M., Subramanyam B.V., Sarmah P.C. and Gupta A.K. (1979): Homicide by Multiple Firearms - Paper Presented at 1 st Annual Conference of Indian Association of Forensic Medicine.

21. Das Gupta, S.M. and Tripathi, C.B. (1983): A Study of the Homicide Cases Occurring in Varanasi Area. Indian Medical Gazette September, 1983. p. 285-288.

22. Das Gupta, S.M., Subsahmayan, B.V., Yadwad, B.S. and Kaviya, V.D. (1979): Trends in Homicide Journal of Indian Academy of Forensic Science. 18(1): 13.

23. Gibbens T.C.N. (1958): Sane and Insane Homicide. The Jr. Crim Law, Criminology and Police Sci. 49(2):110-115. 


\section{ORIGINAL ARTICLE}

24. Gilmore 1I.R (1954): Medical Aspects of the Assassination of Abraham Lincoln. Proc. R. Soc. Med. 47:103. i

25. Govt. of India Ministry of Law (1967): The Probation of Offenders Act, 1958, Government of Indian Press, Delhi.

26. Gupta A.K., Das Gupta S.M. and Rastogi B.L. (1979): Study of Injuries from Firarm in Medicolegal Autospies. Thesis Submitted for the Degree of Doctor of Medicine (Forensic Medicine), Institute of Medical Science, B.H.U., Varanasi.

27. Lombroso, Cerare (1911): Criminal Man According to Classification, New York, Putnam.

28. Modi's Text Book of Medical Jurisprudence and Toxicology. Edited by Modi, N.J. 1983 20th Edn.

29. Parikh's Simplified Text Book of Medical Jurisprudence and Toxicology. Partkh C.K.,Edn., 1983.

30. Personal Communication with the Caretaker Ramnagar Fort, Fort Museum Near Varanasi.

\section{AUTHORS:}

1. Rajeev Kumar

\section{PARTICULARS OF CONTRIBUTORS:}

1. Professor \& Head, Department of Forensic Medicine \& Toxicology, Gold Field Ins titute of Medical Sciences \& Research, Chhainsa, Ballabgarh, Faridabad.

\section{NAME ADDRESS EMAIL ID OF THE} CORRESPONDING AUTHOR:

Dr. Rajeev Kumar,

Professor \& Head,

House No. - 877, 2nd Floor,

Sector - 40, Gurgaon, PIN - 122001.

Email - rajeevkyam@gmail.com

Date of Submission: 24/09/2013.

Date of Peer Review: 01/10/2013.

Date of Acceptance: 18/10/2013.

Date of Publishing: 28/10/2013 